\title{
Mineralogical and Geochemical Appraisal of Clay Deposits in Papalanto and Its Environs, Southwestern, Nigeria
}

\author{
Adewole John Adeola ${ }^{1} \&$ Modupe Adefunmi Olaleye $^{1}$ \\ ${ }^{1}$ Department of Geology and Mineral Sciences, Crawford University, Igbesa, Ogun State, Nigeria \\ Correspondence: Adewole J. Adeola, Department of Geology and Mineral Sciences, Crawford University, Igbesa, \\ Ogun State, Nigeria. Tel: 234-803-812-0171. E-mail: johnadeola@crawforduniversity.edu.ng
}

Received: July 21, 2017

Accepted: July 25, 2017

Online Published: August 22, 2017

doi:10.5539/esr.v7n1p1

URL: https://doi.org/10.5539/esr.v7n1p1

\begin{abstract}
Three residual clay occurrences in Papalanto, Ifo, and Imoto areas which belong to the sedimentary basin of southwestern Nigeria were investigated to determine their industrial applications.

The samples were pulverized, sieved, digested with mineral acids and characterized. Clay mineralogy was determined using X-ray Diffraction (XRD). Elemental compositions of the clay samples were determined using Inductively Coupled Plasma-Mass Spectrometer (ICP-MS). Grain size distribution data were obtained by conducting grain size analysis in two parts; sieve analysis and sedimentation. Thermal properties, plasticity tests, density measurement, linear shrinkage and water absorption capacity were determined to evaluate their industrial potentials. Chemical Index of Alteration (CIA) was calculated to determine the degree of weathering in the area.

The X-ray diffraction results showed that kaolinite is the dominant mineral, while quartz, anatase and hematite are the major non clay minerals. Chemical data showed that the average values of $\mathrm{SiO}_{2}, \mathrm{Al}_{2} \mathrm{O}_{3}$, and $\mathrm{Fe}_{2} \mathrm{O}_{3}$ were $59.46 \%, 22.16 \%$, and $3.06 \%$ respectively constituting $98.3 \%$ of the bulk compositions. Papalanto possessed high plasticity and mouldability.

Evaluation of the clay thermal characteristics, firing colour, water absorption capacities and shrinkage values showed that the whitish Ifo clay and Papalanto kaolinitic clays could serve as raw materials for ceramics, building bricks, and other structural wares. Kaolin which is the dominant mineral in all the clays can be used for cosmetics, tooth paste, pharmaceutical purposes
\end{abstract}

Keywords: clay, structural wares, ceramics, anatase, building bricks

\section{Introduction}

Clay minerals typically form over long periods of time from the gradual chemical weathering of rocks, usually silicate-bearing, by low concentrations of carbonic acid and other diluted solvents. These solvents, usually acidic, migrate through the weathering rock after leaching through upper weathered layers. In addition to the weathering process, some clay minerals are formed through hydrothermal activity. There are two types of clay deposits: primary and secondary. Primary clays form as residual deposits in soil and remain at the site of formation and secondary clays are clays that have been transported from their original location by water erosion and deposited in a new sedimentary deposit. Clay deposits are typically associated with very low energy depositional environments such as large lakes and marine basins.

From prehistoric times, clay has been indispensable in architecture, in industry, and in agriculture. As a building material, it is used in the form of brick, either sun-dried or fired. Clays are also of great industrial importance, e.g., in the manufacture of tile for wall and floor coverings, porcelain, china, and earthenware, pipe for drainage and sewage. Highly absorbent bentonite is much used in foundry work for facing the moulds and preparing the moulding sands for casting metals. The less absorbent bentonite is used chiefly in the oil industry as filtering and deodorizing agents in the refining of petroleum. Clay is a good raw material for paper, ceramics, plastics, and rubber industries. Clays mixed with other materials serve as drilling muds to protect the cutting bit while drilling. Other uses are in the making of fillers, sizings, in purifying sewage. Clays are very useful raw materials from which many domestic and commercial wares can be manufactured (Adeola 2014, Oyinloye 1991, Bolarinwa and Adeola 2017). In Nigeria, clay deposits have not been utilized adequately considering the qualities of this type of industrial mineral that occurs in the country. This may be due to lack of geological information on the 
assessment of the clay deposits and what they can be used to manufacture. It is very pertinent that the physical and chemical properties of any clay deposit should be ascertained for industrial uses and dressings in construction

The present investigation is intended to study the physical, chemical, mineralogical and industrial characteristics of the clay deposits in Papalanto and its environs appraise their economic potentials. This obviously will complement previous studies that were mainly on geochemistry of limestone, shale in the area.

\section{Geological Setting}

Papalanto and its environs is situated in the South-western part of Nigeria and falls within the Dahomey Basin. (Fig. 1)

The Dahomey Basin is a combination of inland/coastal/offshore basin that stretches from southeastern Ghana through Togo and the Republic of Benin to southwestern Nigeria. It is separated from the Niger Delta by a subsurface basement high referred to as Okitipupa Ridge. Its offshore extent is poorly defined. Sediment deposition follows an east-west trend. In the republic of Benin, the geology is fairly well known. In the onshore, cretaceous strata are about $20 \mathrm{~m}$ thick. A non-fossiliferous basal sequence rests on the Precambrian basement. This is succeeded by coal cycles, clays and marls which contain fossiliferous horizons. Offshore, a 1000m thick sequence consisting of sandstones followed by black fossiliferous shale towards the top has been reported. This was dated by Billman (1976) as being pre-Albian to Maastrichtian. The cretaceous is divisible into two geographic zones, north and south. The sequence in the northern zone consists of a basal sand that progressively grades into clay beds with intercalations of lignite and shales. The uppermost beds of the Maastrichtian are almost entirely argillaceous. The southern zone has a more complicated stratigraphy with limestone and marl beds constituting the major facies. Sedimentation in the northern zone which is located inland and close to the basin periphery, began during the Maastrichtian when a thin sequence $(<200 \mathrm{~m})$ of unconsolidated sands, grits, silts, clays and shales, was deposited. This sequence rests on the basement; the transitional facies is marked by a conglomerate or white to grey sandy and kaolinitic clays derived as degradation products from the surrounding Precambrian rocks. In the southern zone, which is coastal and offshore, the oldest sediments consist mainly of loose sand, grits, sandstones and clay with shale interbeds which progressively grade into shale. They are late Albian and possibly Neocomian in age (Omatsola and Adegoke, 1981). The basal conglomerates have been reported from outcrops and boreholes (Jones and Hockey, 1964). The onshore sequence towards the basin periphery in Nigeria correlates well with the Maastrichtian onshore in the republics of Benin and Togo. The geology of Togo sector is very similar to that of Nigerian and Benin sectors. The cretaceous succession shows marked lithological changes which have been expressed in terms of formal and informal lithostratigraphic nomenclature by previous workers. This can lead to dual or multiple nomenclature and thus confusion.

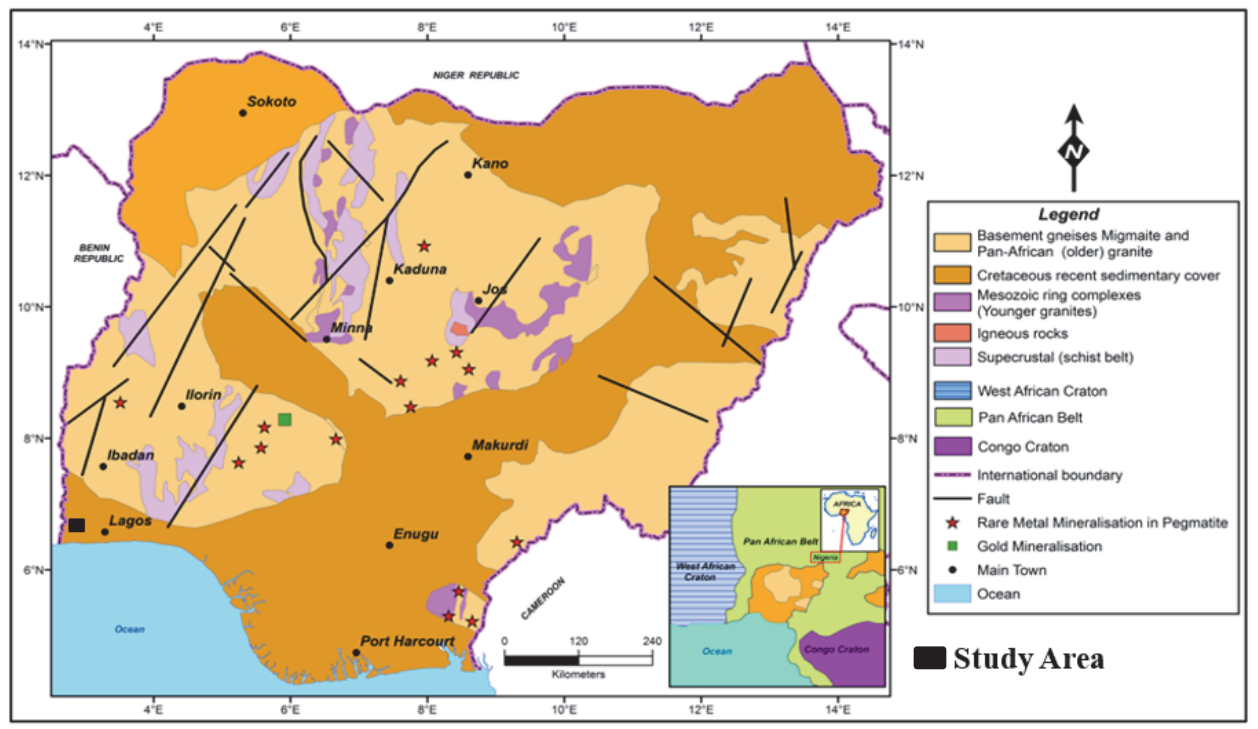

Figure 1. Map of Nigeria showing the location of the study area

Among the major lithostratigraphic units of the eastern Dahomey basin are the Araromi, Ewekoro, and Akinbo formations. The Dahomey basin is one of the sedimentary basins on the continental margin of the Gulf of Guinea, extending from southeastern Ghana in the west to the western flank of the Niger Delta (Jones and Hockey, 1964; 
Omatsola and Adegoke, 1981. The basin is bounded in the west by faults and other tectonic structures associated with the landward extension of the fracture zone. Its eastern limit is similarly marked by the Hinge line, a major fault structure marking the western limit of Niger Delta (Adegoke, 1969; Omatsola \& Adegoke,1981). It is also bounded in the north by the Precambrian basement rock and the Bright of Benin in the south (Fig 2).

Stratigraphic studies of Dahomey basin were conducted by various researchers among whom are Jones and Hockey, (1964); Adegoke.(1975); Omatsola and Adegoke, (1981). The general sequence for the rock unit from the top are the Coastal plain sands, Ilaro formation, Oshosun formation, Akinbo formation, Ewekoro formation, and Abeokuta formation lying on the Southwestern Basement Complex of Nigeria (Fig. 3)

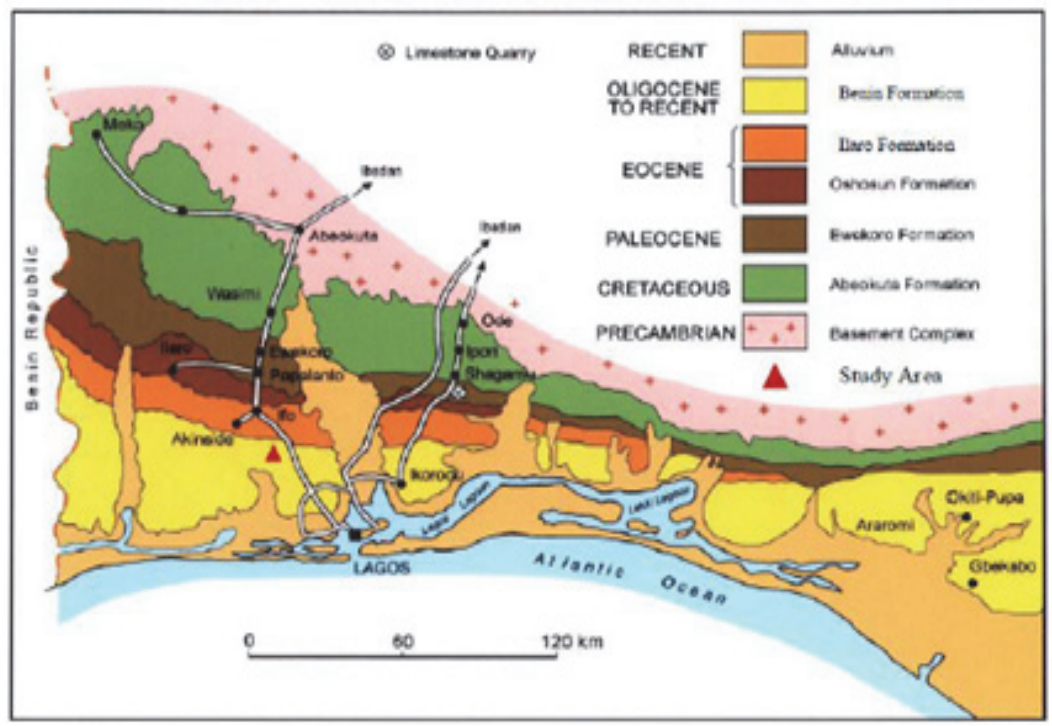

Figure 2. Map of Eastern Dahomey basin showing the stratigraphic setting

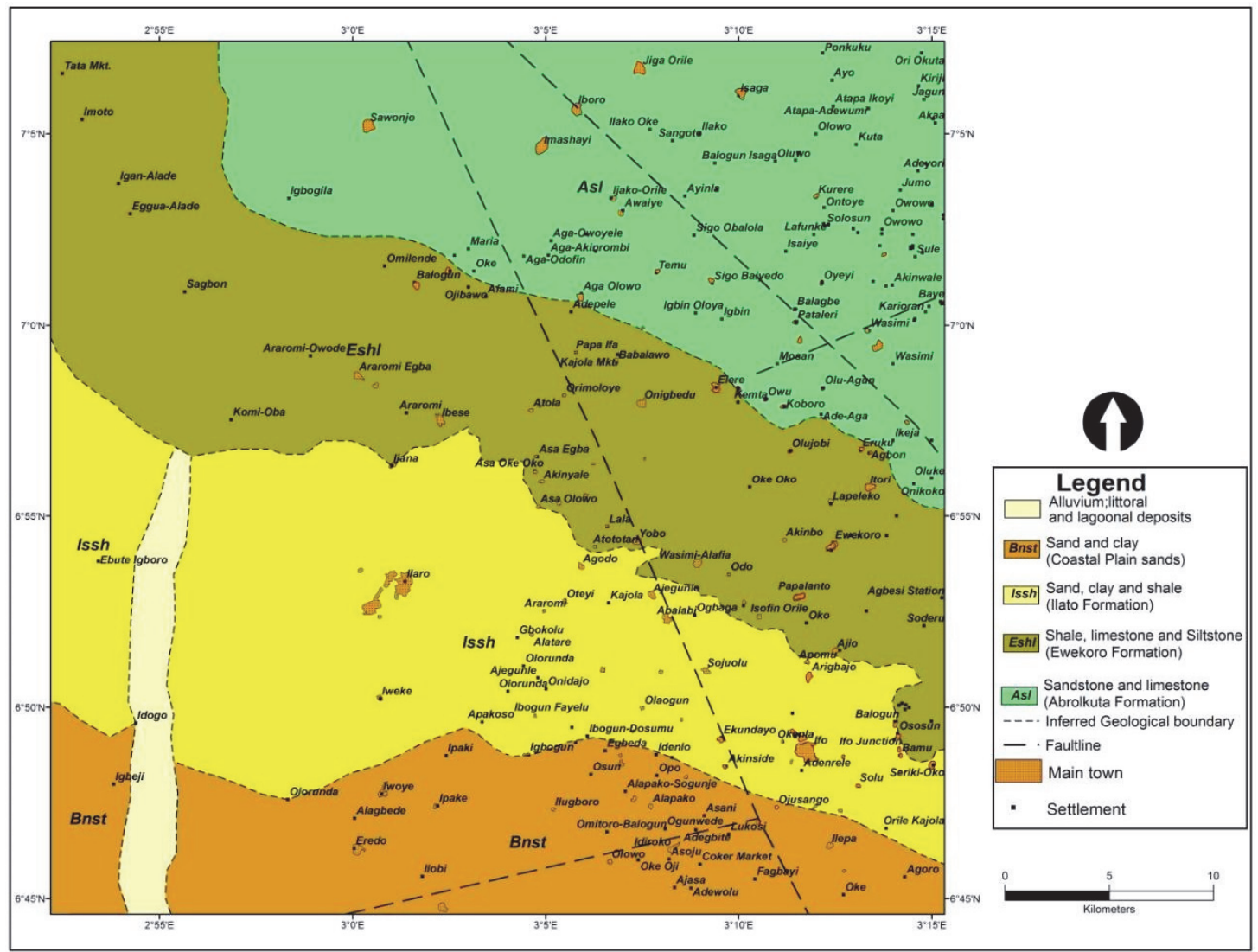

Figure 3. Geologic map of Papalanto and its environs 


\section{Materials and Method}

Thirty two fresh representative samples were collected from the three locations. Eight samples from each of the locations were prepared for physical and chemical analyses. Hydrometer method and wet sieving analyses were used to determine the grain size distribution of Ifo, Papalanto and Imoto clays. Liquid and Plastic limits were determined using Cassangrade (1948) apparatus. Representative samples were made into pellets using a pressure gauge these pellets were fired at about $950^{\circ} \mathrm{C}$ for about 24 hours to determine the shrinkage capacity and colour change of the clay deposits. Samples were also selected for the thermal tests. Clay mineralogy was determined using X-ray Diffraction (XRD) at Activation Laboratory in Canada. The X-ray diffraction analysis was performed on a analytical X'Pert Pro diffractometer, equipped with a $\mathrm{Cu} X$-ray source and an X'celerator detector, operating at the following conditions: voltage - $40 \mathrm{kV}$; current $-40 \mathrm{~mA}$; range $-5-80^{\circ} 2 \theta$; step size: $0.017,{ }^{\circ} 2 \theta$; time per step: $50 \mathrm{~s}$; divergence slit: fixed, angle $0.5^{\circ}$. The crystalline mineral phases were identified by X'Pert HighScore Plus software using the PDF-4 ICDD database. The quantities of the crystalline minerals were determined using the Rietveld method. The Rietveld method is based on the calculation of the full diffraction pattern from crystal structure information. Elemental compositions of the clay samples were determined using Inductively Coupled Plasma-Mass Spectrometer (ICP-MS) at Activation Laboratory, Canada . For ICP-MS, microwave high pressure/temperature decomposition of samples $\left(230^{\circ} \mathrm{C}, 7.0 \mathrm{MPa}\right.$; Paar Physical Multiwave sample preparation system) using Merck Suprapurs grade reagents ( $\mathrm{HF}, \mathrm{HCIO}_{4}, \mathrm{HNO}_{3}$ and $\mathrm{HCl}$ ). All measurements were made on a Sciex/Perkin-Elmer ELAR 6000 ICP-MS. The Chemical Index of Alteration (CIA $\left.=\mathrm{Al}_{2} \mathrm{O}_{3} / \mathrm{Al}_{2} \mathrm{O}_{3}+\mathrm{CaO}+\mathrm{Na}_{2} \mathrm{O}+\mathrm{K}_{2} \mathrm{O}\right) \mathrm{X} 100$, where all components expressed in molecular proportions was calculated to measure the Intensity of Chemical Weathering (ICW) of soils.

\section{Results and Discussion}

\subsection{Field work and Macro-Petrography}

Profile 1 is located within the sedimentary basin of Nigeria at Ifo area, Southwestern Nigeria. It is located on latitude $\mathrm{N}^{\circ} 6^{\circ} 45^{\prime} 75^{\prime \prime}$ and longitude E003 $12^{\prime} 9^{\prime \prime}$. A $9 \mathrm{~m}$ thick profile is exposed along Ifo-Abeokuta expressway. There is no evidence of large scale movement and the different horizons within the profile grades into each other. Three distinct layers were identified based on colour and texture. (Fig. 4a).

The upper horizon which is the topsoil is generally light brown in colour and is about $0.8 \mathrm{~m}$ thick with texturally fine grained containing plant roots and humus. Underlying this horizon is a medium grained, reddish-brown laterite layer of about $4 \mathrm{~m}$ in thickness. This layer contains no humus or organic materials like the topsoil. Underlying the laterite layer is the clay horizon. This clay is fine grained in texture and is whitish in color with some patches of purple and brown. It is about $5 \mathrm{~m}$ in thickness.

Profile 2 is located at Papalanto area on latitude N06 $53^{\prime} 28^{\prime \prime}$ and longitude E003 $07^{\prime} 84^{\prime \prime}$.

A $8.5 \mathrm{~m}$ thick profile is exposed at Ajegunle Bus-Stop along Papalanto-Ilaro road, There is no evidence of large scale movement and the different horizons within the profile also grades smoothly into each other like Ifo profile. Based on colour and textural characteristics, three distinct layers were identified (Fig. $4 \mathrm{~b}$ ).

The upper horizon which is the topsoil is about $0.5 \mathrm{~m}$ thick and brown in colour. It is fine grained in texture and contains lots of plant roots and humus. Directly below this horizon is the reddish-brown laterite layer of about $5 \mathrm{~m}$ in thickness and grades gradually into the underlying clayey horizon. The clay deposit is vast in this area. This clay deposit is fine grained in texture and whitish in colour with some patches of colour purple and brown.

Profile 3 is located within the sedimentary terrain at Imoto area. It is located on latitude N07 $05^{\prime} 43.6^{\prime \prime}$ and longitude $\mathrm{E} 04^{\circ} 18^{\prime} 9.52^{\prime \prime}$. A $5 \mathrm{~m}$ thick profile is exposed in a quarry near Igan-Alade, Igbogila. Based on colour and textural characteristics, two distinct layers were identified (Fig. 4c). The topsoil is light brown in colour and is about $0.5 \mathrm{~m}$ thick. It is fine grained in texture and contains lots of plant roots and humus. Directly below this horizon is the clayey horizon. This clay is fine grained in texture and is dark grey in colour.

\subsection{Mineralogy}

The X-ray difractograms derived from Ifo, Papalanto and Imoto clays show that kaolinite is the dominant clay mineral in the profiles. Conspicuous peaks of kaolinite are recorded at $\mathrm{d}=\sim 7.14 \AA, \mathrm{d}=\sim 4.36 \AA$ and $\mathrm{d}=\sim 3.57 \AA$ in the oriented and non-glycolated samples. Quartz is the major non clay mineral that is present in all the horizons in the profiles because of its high resistance to weathering. Anatase and hematite occur as traces in all the profiles in the area (Fig 5).

\subsection{Chemical Compositions}

The average chemical compositions of major and trace elements in the clays are presented in Table 1 . The mean 
compositions of $\mathrm{SiO}_{2}$ in Ifo, Papalanto and Imoto area are $60.35 \%, 56.47 \%$, and $61.95 \%$ respectively. This shows that the $\mathrm{SiO}_{2}$ in Imoto clay profile is very high. This might be due the presence of high concentration of quartz as recorded in Table 1 . The enhanced value of $61.95 \%$ in the clay may be due to relative depletion of $\mathrm{MnO}, \mathrm{MgO}$, $\mathrm{CaO}, \mathrm{Na}_{2} \mathrm{O}, \mathrm{K}_{2} \mathrm{O}$ in the horizon and could be said that quartz which is of secondary origin probably accumulated from the chemical weathering of rock forming silicates. The weathering and dissolution of silicate minerals consequently led to the enrichment of $\mathrm{SiO}_{2}$ and $\mathrm{Fe}_{2} \mathrm{O}_{3}$ in the topsoil. The X-ray diffractogram of the clay show prominent peaks of quartz probably due to their relative crystallinity (Brindly 1961).

The concentration of $\mathrm{Al}_{2} \mathrm{O}_{3}$ ranges from 15.57 to $26.15 \%$. The aluminium concentration in Papalanto clay is the highest $(26.15 \%)$ and the lowest values are recorded in Imoto clay $(15.57 \%) . \mathrm{Fe}_{2} \mathrm{O}_{3}$ is generally low in the clays in this area except in Imoto clay. The concentration of Fe ranges from 2.17 to $6.72 \%$. The brownish colour of moto clay can be attributed to the presence of high concentration of iron as evidenced in Table 1. This is strongly supported by several peaks of hematite in the X ray diffractogram of Imoto clay (Fig. 5).

The following low values $\mathrm{CaO}, \mathrm{Na}_{2} \mathrm{O}, \mathrm{K}_{2} \mathrm{O}, \mathrm{P}_{2} \mathrm{O}_{5}, \mathrm{MgO}$ and $\mathrm{LOI}$ strongly indicate leaching during chemical weathering. The concentration values for $\mathrm{CaO}$ are $0.02 \%, 0.02 \%$, and $0.17 \%, \mathrm{Na}_{2} \mathrm{O}$ are $0.02 \%, 0.04 \%$, and $0.10 \%$, a nd $\mathrm{P}_{2} \mathrm{O}_{5}$ are $0.07 \%, 0.06 \%$ and $0.05 \%$ in Ifo, Papalanto and Imoto respectively. $\mathrm{TiO}_{2}$ is relatively low in all the clays but high in Imoto clay with average of $(1.96 \%) . \mathrm{P}_{2} \mathrm{O}_{5}$ is relatively low in all the clays.

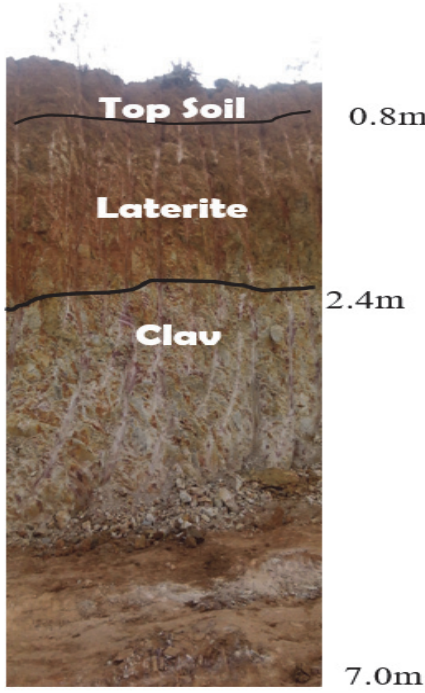

(a)

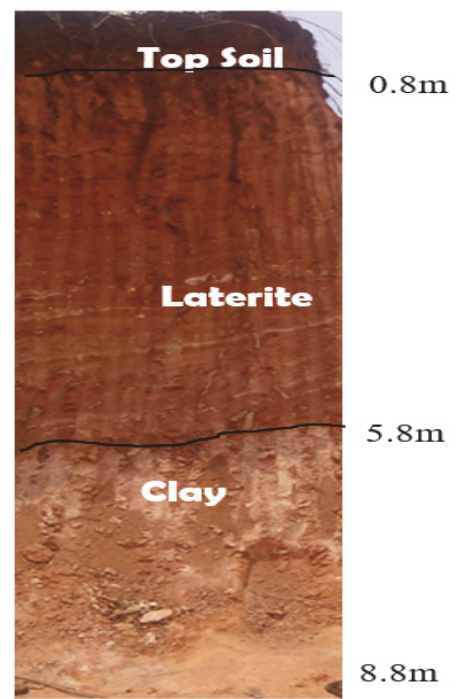

(b)

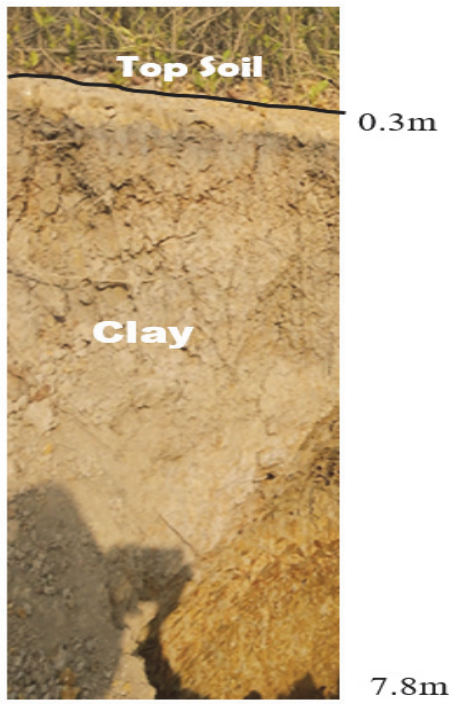

(c)

Figure 4. Weathered profiles of the study area. (a) - Ifo clay body, (b) - Papalanto clay, (c )- Imoto clay body

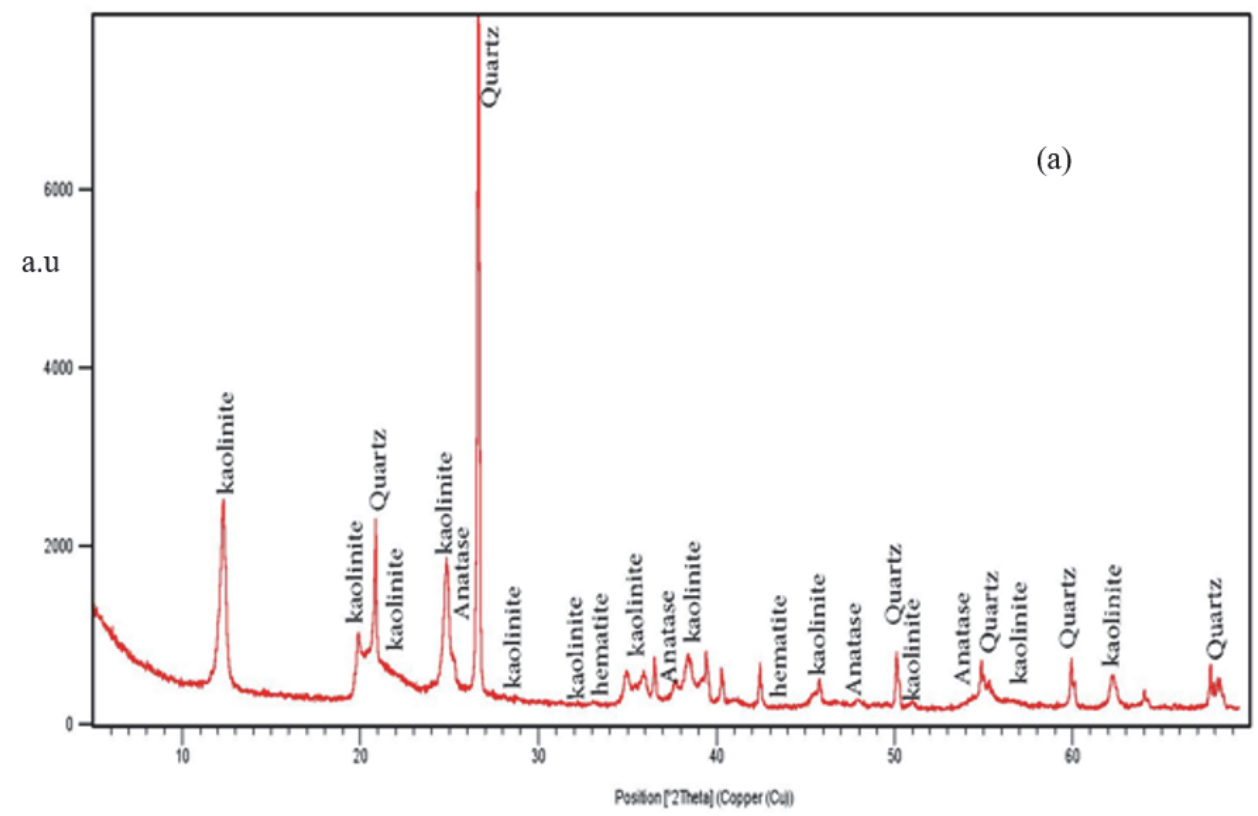



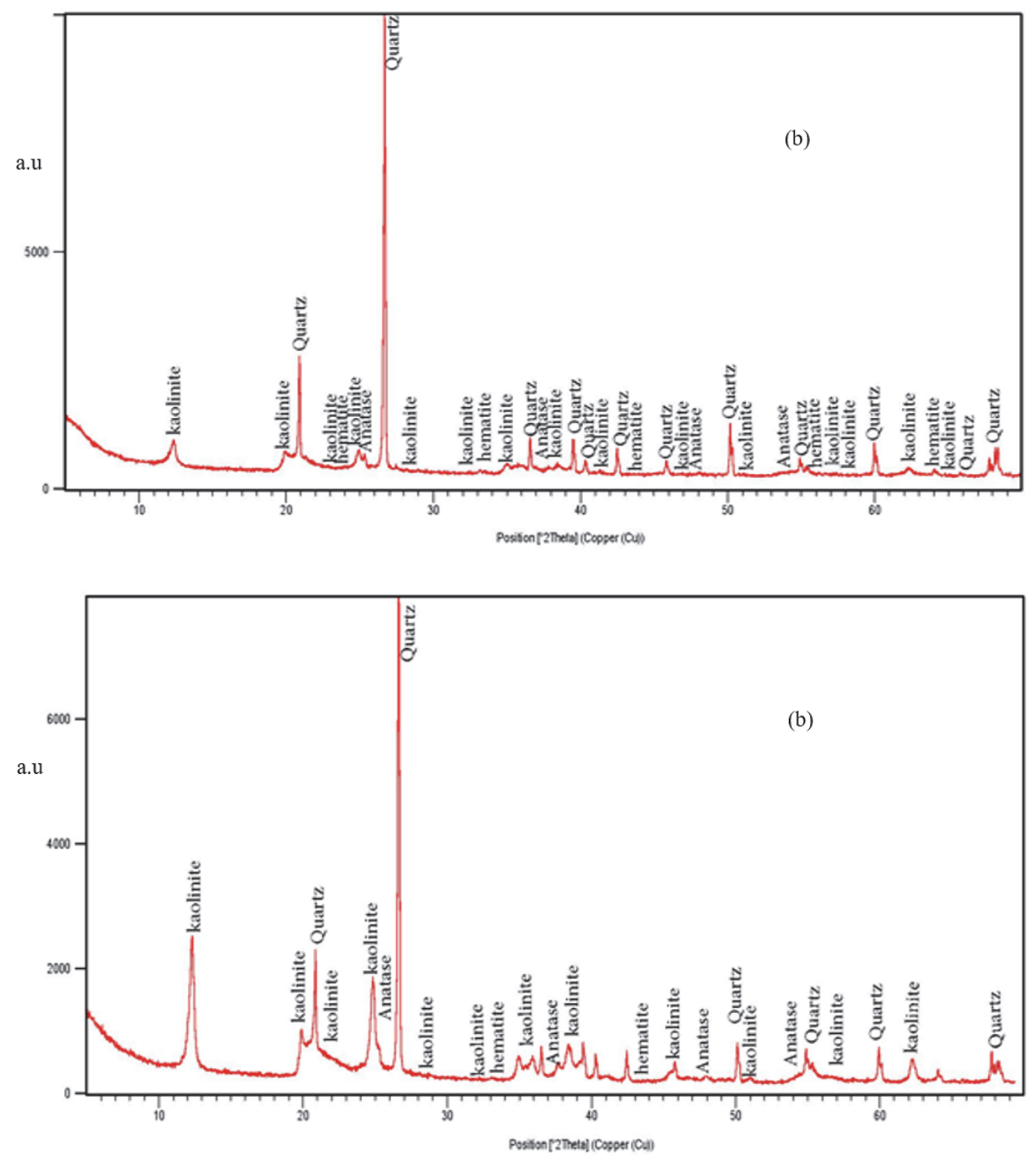

Figure 5. X-ray diffraction diagrams for the clay samples (a) Ifo clay, (b) Papalanto clay, (c) Imoto clay

The trace element Ba is relatively high in Ifo clay (129ppm) and Papalanto clay (123ppm) but low in Imoto clay with average of $(68.60 \%)$. $\mathrm{Zr}$ and $\mathrm{V}$ are relatively high while $\mathrm{Sc}, \mathrm{Be}$ showed low values in Ifo, Papalanto and Imoto clays. Silica ratio (S.R) is high in Imoto clay but relatively low in Ifo clay and Papalanto clay with averages of $(4.61 \%)$ and $(4.85 \%)$ respectively. Alumina ratio (A.R) is relatively low in Imoto clay with average of $(2.31 \%)$ but high in Ifo clay (11.41\%) and Papalanto clay (9.72\%).

Major elements abundances show that the clay samples have $\mathrm{SiO}_{2}$ (ca. 59.46\%), $\mathrm{Al}_{2} \mathrm{O}_{3}$, (ca 22.16\%), and $\mathrm{Fe}_{2} \mathrm{O}_{3}$ (ca 3.06\%) constituting $98.3 \%$ of the bulk compositions. $\mathrm{Al}_{2} \mathrm{O}_{3}$ content is higher in Ifo and Papalanto but lower in Imoto. The $\mathrm{Fe}_{2} \mathrm{O}_{3}$ is relatively higher in Imoto compared with other clays. $\mathrm{Fe}_{2} \mathrm{O}_{3} \mathrm{MgO}, \mathrm{MnO}, \mathrm{CaO} \mathrm{Na} 2 \mathrm{O}$ and $\mathrm{TiO}_{2}$ are higher in Imoto clay than clay samples from Papalanto and Ifo.

The $\mathrm{SiO}_{2}, \mathrm{Al}_{2} \mathrm{O}_{3}$, and $\mathrm{Fe}_{2} \mathrm{O}_{3}$ of Papalanto clay compared favourably with Plastic Fire clay (Huber, 1985) as presented in the chemical compositions (Table 2) except that the $\mathrm{Al}_{2} \mathrm{O}_{3}$ is slightly higher .In terms of functional applications, Ifo Papalnto and Imoto chemical compositions are within the limits of industrial applications for ceramics and refractories (Table 3).

The Chemical Index of Alteration ( $\left.\mathrm{CIA}=\mathrm{Al}_{2} \mathrm{O}_{3} / \mathrm{Al}_{2} \mathrm{O}_{3}+\mathrm{CaO}+\mathrm{Na}_{2} \mathrm{O}+\mathrm{K}_{2} \mathrm{O}\right) \mathrm{X}$ 100, where all components expressed in molecular proportions is commonly used as a measure of the Intensity of Chemical Weathering (ICW) of soils. This parameter was derived by (Nesbitt and Young 1982, 1984). Nesbitt indicated that CIA values between 30-55 is an indication of weathering at incipient zone, and CIA values ranging between 51-85 
could be considered as intermediate zone of weathering while weathering that is at the advanced stage will have CIA values greater than 85. From the values of Chemical Index of Alteration (CIA) calculated above, the CIA values for Ifo, Papalanto and Imoto clays are $99.27 \%, 98.75 \%$ and $95.28 \%$ respectively. It can be inferred that the weathering that resulted in the formation of these clays have reached advanced stage because all the CIA values are greater than $85 \%$ (Table 1).

\subsection{Industrial Properties}

The industrial properties of clay such as thermal characteristics, loss on ignition, fired colour, water absorption capacities and shrinkage were evaluated. The summary of the results of the industrial properties are presented in table 4. Loss on ignition ranges between $11.65 \%$ - $11.96 \%$ with a mean of $11.75 \%$. The average values of water absorption capacities of fired pellets after immersion in cold water for 24 hours range from $12.09 \%-17.14 \%$ with Imoto (17.14\%) having the highest water absorption capacity.

The concentration of the iron compounds that are present in the samples determined the colour of the fired samples that ranged from brown to reddish brown. The average linear shrinkage is higher in Ifo and Papalanto(15\%) clay samples than Imoto Clay (11\%). The results of the wet analysis show that the average clay fraction of (Papalanto (85.4\%) is greater than Ifo (69.4\%)and Imoto (44.5\%)clay. Plots of the plasticity indices against liquid limits values (Fig. 7) classify Papalanto, Ifo and Imoto clays as inorganic clays and inorganic silts with moderate compressibility and moderate toughness.

Table 1. Average chemical compositions (\%) of major and minor oxides of clays in study area

\begin{tabular}{|c|c|c|c|c|c|c|}
\hline \multicolumn{3}{|c|}{ Ifo } & \multicolumn{2}{|l|}{ Papalanto } & \multicolumn{2}{|l|}{ Imoto } \\
\hline Oxides & Mean & Range $n=3$ & Mean & Range $n=3$ & Mean & Range $n=3$ \\
\hline $\mathrm{SiO}_{2}$ & 60.35 & $59.57-61.97$ & 56.47 & $53.71-57.77$ & 61.95 & $61.52-62.52$ \\
\hline $\mathrm{Al}_{2} \mathrm{O}_{3}$ & 24.76 & $23.61-25.47$ & 26.15 & $25.40-27.13$ & 15.57 & $15.32-15.80$ \\
\hline $\mathrm{Fe}_{2} \mathrm{O}_{3}$ & 2.17 & 2.14-2.19 & 2.69 & $2.41-3.25$ & 6.72 & 6.42-6.96 \\
\hline $\mathrm{MnO}$ & 0.01 & $0.01-0.01$ & 0.02 & $0.02-0.02$ & 0.03 & $0.03-0.03$ \\
\hline $\mathrm{MgO}$ & 0.05 & $0.04-0.05$ & 0.06 & $0.06-0.06$ & 0.41 & $0.41-0.42$ \\
\hline $\mathrm{CaO}$ & 0.02 & $0.02-0.02$ & 0.02 & $0.02-0.02$ & 0.17 & $0.17-0.17$ \\
\hline $\mathrm{Na}_{2} \mathrm{O}$ & 0.02 & $0.02-0.02$ & 0.04 & $0.03-0.04$ & 0.10 & $0.10-0.10$ \\
\hline $\mathrm{K}_{2} \mathrm{O}$ & 0.09 & $0.09-0.01$ & 0.21 & $0.19-0.23$ & 0.09 & $0.09-0.10$ \\
\hline $\mathrm{TiO}_{2}$ & 1.73 & $1.39-1.88$ & 1.58 & $1.54-1.65$ & 1.96 & $1.94-1.98$ \\
\hline $\mathrm{P}_{2} \mathrm{O}_{5}$ & 0.07 & $0.05-0.10$ & 0.06 & 0.05-0.06 & 0.05 & 0.05-0.06 \\
\hline LOI & 10.55 & $10.38-10.64$ & 11.93 & $11.59-12.47$ & 11.99 & $11.80-12.33$ \\
\hline TOTAL & 99.82 & $99.31-100.3$ & 99.23 & $98.50-100.5$ & 99.06 & $98.40-99.40$ \\
\hline \multicolumn{7}{|c|}{ Trace Elements (ppm) } \\
\hline $\mathrm{Ba}$ & 129.00 & $99-140$ & 123.00 & $114-128$ & 68.60 & $68-70$ \\
\hline $\mathrm{Sr}$ & 104.30 & $56-123$ & 49.00 & $47-50$ & 46.60 & $46-48$ \\
\hline Y & 25.50 & $20-28$ & 30.00 & $29-32$ & 58.00 & $58-58$ \\
\hline $\mathrm{Sc}$ & 11.50 & $10--12$ & 12.00 & $12--12$ & 19.00 & 19-19 \\
\hline $\mathrm{Zr}$ & 920.50 & 698--1042 & 968.00 & $949-978$ & 945.60 & $935-958$ \\
\hline $\mathrm{Be}$ & 1.00 & $1--1$ & 1.00 & $1--1$ & 4.00 & 4--4 \\
\hline $\mathrm{V}$ & 129.00 & $97-140$ & 104.00 & $98-115$ & 130.60 & $128-132$ \\
\hline \multicolumn{7}{|c|}{ Silica and Alumina Ratio \% } \\
\hline SR & 4.61 & $4.52-4.79$ & 4.85 & $4.65-5.22$ & 10.69 & $10.37-10.90$ \\
\hline AR & 11.41 & $10.88-11.68$ & 9.72 & $8.34-10.56$ & 2.31 & 2.24-2.46 \\
\hline $\mathrm{MgO}+\mathrm{CaO}$ & 0.07 & 0.06-0.07 & 0.08 & $0.08-0.08$ & 0.58 & $0.58-0.59$ \\
\hline $\mathrm{Na}_{2} \mathrm{O}+\mathrm{K}_{2} \mathrm{O}$ & 0.11 & $0.11-0.12$ & 0.20 & $0.5-0.27$ & 0.19 & 0.2-0.19 \\
\hline CIA & 99.27 & & 98.75 & & 95.28 & \\
\hline
\end{tabular}


Table 2. Average chemical composition of Ifo, Papalanto and Imoto residual clays

\begin{tabular}{lcccccc}
\hline Oxides & *Ifo ( \%) & *Papalanto ( \%) & *Imoto ( \%) & $\begin{array}{l}\text { Reference } \\
(\mathrm{A}) \%\end{array}$ & $\begin{array}{c}\text { Reference } \\
(\mathrm{B}) \%\end{array}$ & $\begin{array}{c}\text { Reference } \\
(\mathrm{C}) \%\end{array}$ \\
\hline $\mathrm{SiO}_{2}$ & 60.35 & 56.47 & 61.95 & 52.92 & 57.67 & 46.88 \\
$\mathrm{Al}_{2} \mathrm{O}_{3}$ & 24.76 & 26.15 & 15.57 & 9.42 & 24.00 & 37.65 \\
$\mathrm{Fe}_{2} \mathrm{O}_{3}$ & 2.17 & 2.69 & 6.72 & 3.65 & 3.23 & 0.88 \\
$\mathrm{MgO}$ & 0.05 & 0.06 & 0.41 & 0.08 & 0.30 & 0.13 \\
$\mathrm{CaO}$ & 0.02 & 0.02 & 0.17 & 1.91 & 0.70 & 0.03 \\
$\mathrm{Na}_{2} \mathrm{O}$ & 0.02 & 0.04 & 0.10 & 0.03 & 0.20 & 0.21 \\
$\mathrm{~K}_{2} \mathrm{O}$ & 0.09 & 0.21 & 0.09 & 0.98 & 0.50 & 1.60 \\
$\mathrm{P}_{2} \mathrm{O}$ & 0.07 & 0.06 & 0,05 & 0.02 & - & - \\
$\mathrm{MnO}$ & 0.01 & 0.01 & 0.03 & - & - & - \\
$\mathrm{LOI}$ & 10.47 & 11.93 & 11.99 & 10.19 & 10.50 & 12.45 \\
$\mathrm{Total}$ & 98.01 & 97.64 & 97.03 & 79.20 & 97.10 & 99.83 \\
\hline
\end{tabular}

*Average values for 5 samples
(A) - Florida Active Kaolinite (Huber, 1985)
(B) - Plastic Fire Clay, St Louis (Huber, 1985)
(C) - China Clay (Huber, 1985)

Table 3. Comparison of Ifo, Papalanto and Imoto clays with some industrial chemical specifications

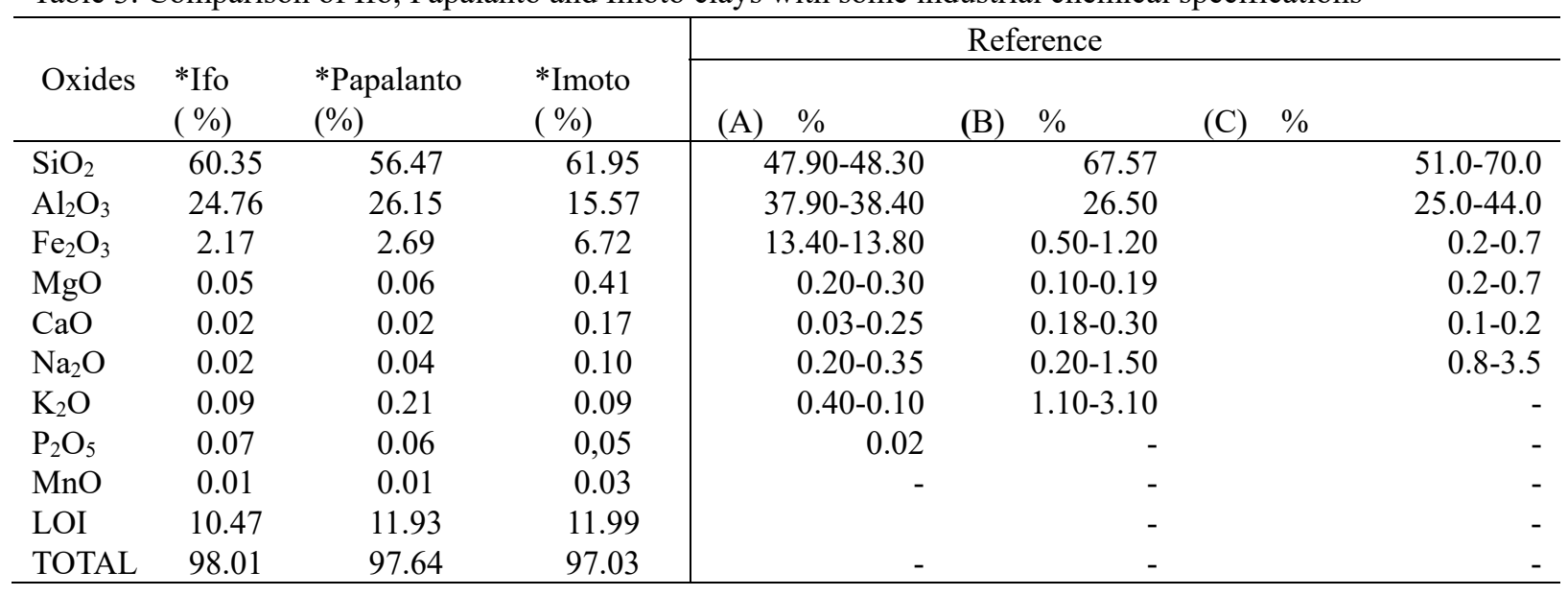

*Average values for 5 samples
(A) - Paints (Payne, 1961)
(B) - Ceramics (Singer and Sonja, 1971)
(C) - Refractory Bricks, (Parker, 1967)

Table 4. Physical and firing properties of the Ifo, Papalnto and Imoto clays

\begin{tabular}{llllllllll}
\hline \multirow{2}{*}{ Profile } & Clay & \multicolumn{9}{c}{ Atterberg Limits } & LOI (\%) & LSK(\%) & WAC(\%) & S.G & Colour \\
& Fraction & LL (\%) & PL (\%) & PI (\%) & & & & & \\
\hline * Ifo clay & 69.4 & 48.96 & 28.55 & 19.96 & 11.65 & 15 & 14.29 & 2.57 & Brown \\
*Papalanto & 85.4 & 52.48 & 34.04 & 20.14 & 11.65 & 15 & 12.09 & 2.55 & Buff brown \\
*Imoto & 44.5 & 49.16 & 28.72 & 21.15 & 11.99 & 11 & 17.14 & 2.60 & Brown \\
\hline
\end{tabular}

* Average values for 5 samples

LOI - Loss on ignition

LSK - Linear Shrinkage

WAC - Water absorption capacity 
LL - Liquid limit

PL - Plasticity limit

PI - Plasticity index

\section{Discussion}

Papalanto, Ifo and Imoto clays are basically residual and dominantly kaolinitic. Ifo and Papalanto clays are the most plastic while Imoto is sandy and characterized with low plasticity. The presence of hematite indicates that the ferromagnesian mineral such as biotite has been mpletely weathered and converted to hematite. This actually responsible for the brown colouration in the clays.

Comparing the chemical composition with the standard industrial references, Ifo, Papalanto and Imoto clays cannot be used for the production of paint because of the high silica and low alumina concentration but they are quite recommended for the production of ceramics. Also, with further beneficiation, all of can serve as good raw materials for the production of refractory bricks.

The composition of the Papalanto clay is quite comparable with Plastic fire clay (Huber, 1985) with further beneficiation and Ifo and Imoto clays can meet the Florida active kaolinite standard. None of the clays can be used as China clays because of the high silica and alumina content

In determining the accurate engineering properties of soil, the proposed Cassangrade (1948) plasticity chart is generally employed (Fig.7) The chart incorporate a boundary called "A-Line" which starts from the liquid limit of 20 and runs diagonally upward to the right with a slope of 0.73 . The line demarcates the inorganic clays from inorganic silts and organic clays. From the result, the liquid limit is higher than the plastic limit (Table 4). This agrees with the general trend observed by Adeyemi (2001). The difference between these two limits called the Plasticity Index is an important geotechnical parameter. When the value of the plastic limit is close to that of the liquid limit, soil is said to be non-plastic. From this result, non of the plasticity and plasticity index values is close to each order. Consequently, the clays in Papalanto area can be said to be plastic. Plots of plastic limit and plasticity indices on the Bain (1971) mouldability chart (Fig. 7) indicate that the clay bodies from pakkshin area generally possess moderate mouldabilitty. It must be noted that the shrinkage and mouldability of the clays, which largely determined the industrial suitability are affected by the grain size distribution and the mineralogy of the clay. Kaolonitic clay have no expandable lattice and therefore have low swelling potential and low shrinkage. Clayey materials this area is mainly kaolinite. This is similar to mouldability of clays above biotite granite, banded gneiss in Abeokuta area by Bolarinwa (2001) .

Based on the percentage of clay, silt, and sand, the textural classification of clays in the study are, Ifo clays plots within the field of (Sandy silt) zone. Papalanto and Imoto clays plot within the field of Sandy mud and sandy silt (Fig.6) due to is moderately high silt and mud. The grain size distribution curves obtained showed that the soils are well graded. The particle size distribution is evenly spread between sand, silt and clay. High amount of coarse fractions in a soil sample and low amount of fines are generally believed to give good subgrade soils as this contribute significantly to the mechanical strength of the soil. These clays would not serve as good subgrade material although due to their high specific gravity but they can be used as filling materials.

Fabbri and Fiori (1985) constructed ternary diagrams based on the chemical and mineralogical compositions of clay raw materials to be used in the of ceramics industry for the production of traditional ceramic products. These ternary diagrams are the most suitable to define and visualize compositional fields. Based on this, only Imoto clay falls near the global fields of red-stone ware and this is suggests that Imoto clay is the only suitable material for the production of red-stone ware products. The chemical composition of Imoto is quite similar to the clay materials from Bailen area and Greece being used for the production of Red-stoneware as reported by Gonzalez et al. (1997) and Oikonomopoulus et al. (2007). The amount of alkalis $\left(\mathrm{Na}_{2} \mathrm{O}+\mathrm{K}_{2} \mathrm{O}\right)$ concentration in Imoto, Papalnto and Ifo clays is favourably compared with Moro and Chulilla clays employed for the production of ceramic in Castellon (Mesenguer 2011) 


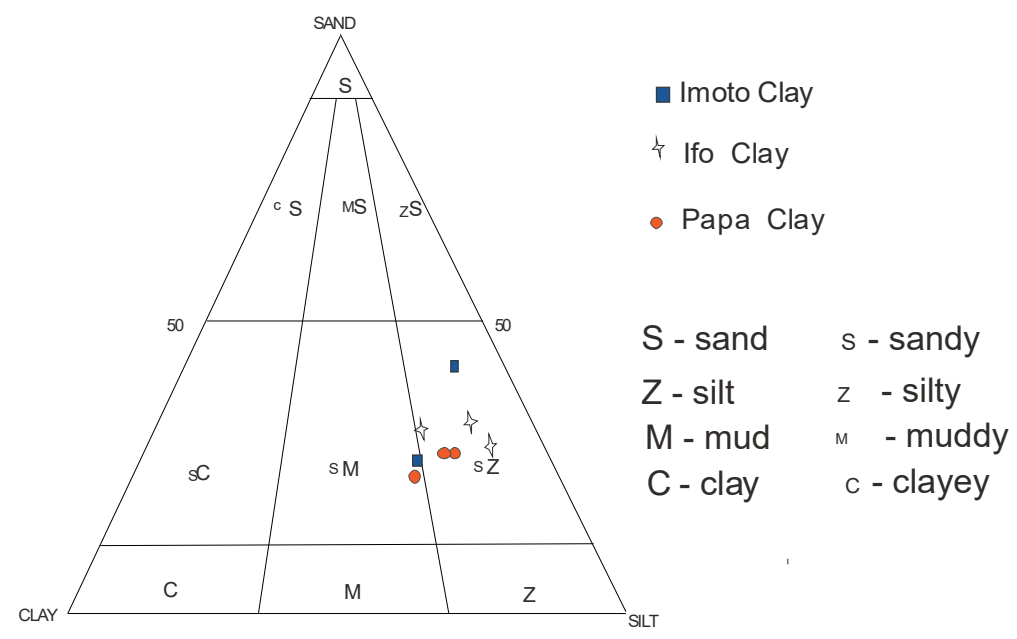

Figure 6. Textural classification of Ifo, Papalanto and Imoto clays (After Folk, 1974)

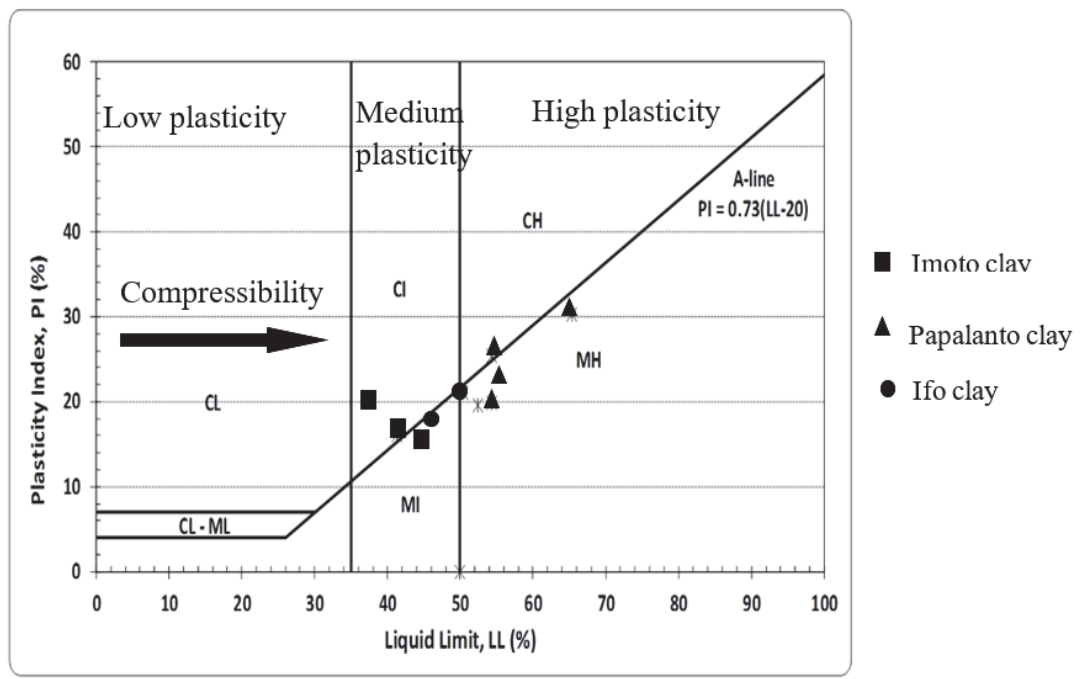

Figure 7. A plasticity chart for the classification of clays from Ifo, Papalanto and Imoto area (after Cassangrande, 1948)

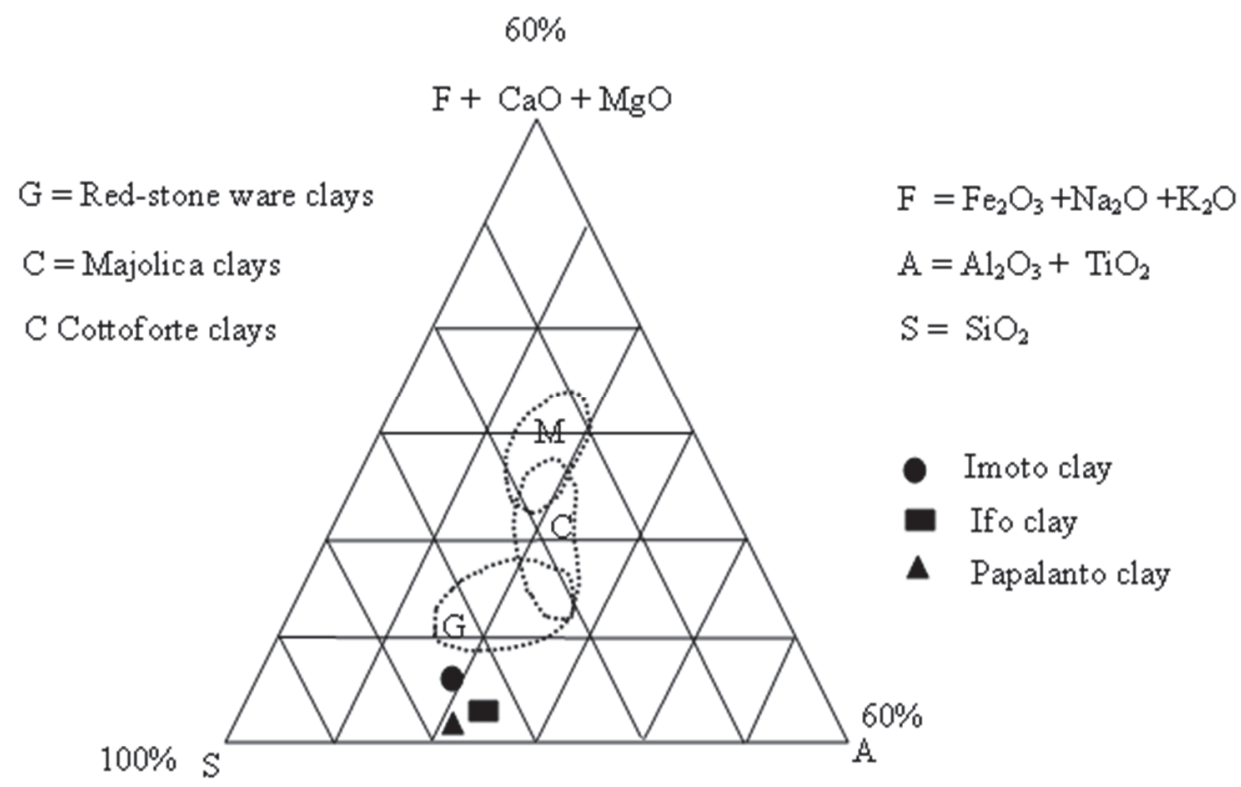




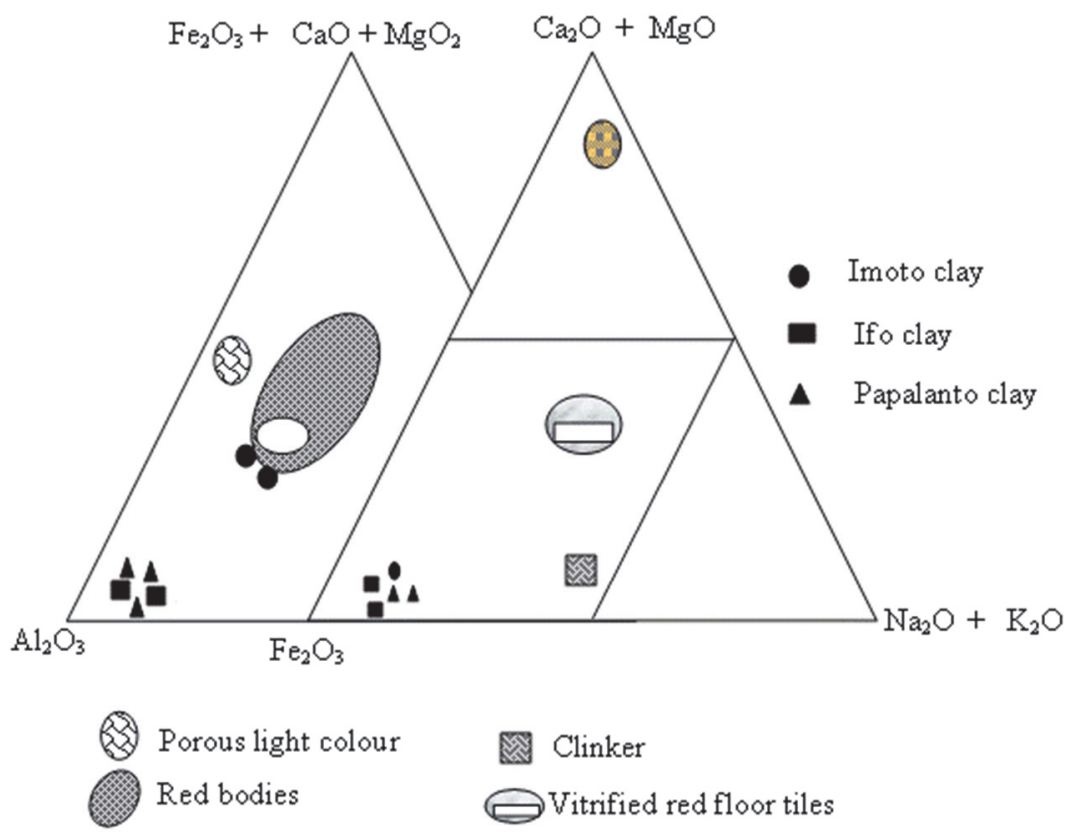

Figure 8. Ternary diagram $\mathrm{SiO}_{2} / \mathrm{Al}_{2} \mathrm{O}_{3}+\mathrm{TiO}_{2} / \mathrm{Fe}_{2} \mathrm{O}_{3}+\mathrm{MgO}+\mathrm{K}_{2} \mathrm{O}+\mathrm{CaO}+\mathrm{Na}_{2} \mathrm{O}$ (Afer Fabbri and

Fiori, 1985)

\section{Conclusion}

The mineralogical study in this area shows that the kaolinite is the dominant mineral in the clay and other non-clay minerals like quartz, hematite and plagioclase occurs as accessory minerals. From the mineralogical and chemical point of viev, moto favours the production of ceramics and paplanto, and Ifo would be adequate for the production of refractories and bunrt bricks. Open pit method is hereby recommended for the mining of these clay deposits because they are generally covered with thin soil layer ranging from $0.3 \mathrm{~m}$ to $0.8 \mathrm{~m}$ in thickness.

\section{References}

Adeola, A. J., \& Dada R. G. (2017). Mineralogical and geochemical trends in lateritic weathering profiles on basement rocks in Awa-Oru Ijebu and its environ, southwestern Nigeria. Global Journal of Geological Sciences, 15, 1-11.

Ajayi, J. O., \& Agagu, O. K. (1981). Mineralogy of primary clay deposits in the basement complex areas ofNigeria. Journal of Mining and Geology, 1(18), 27-30.

Alabo, E. H., \& Fitzjohn, W. H. The effects of pretreatment on the Atterberg limit of red deltaic soil. Journal of mining and Geology, 18(1), 28-29.

Bain, J. A. (1971). A plastic chart as an aid to the identification and assessment of industrial clays, clay minerals.

Barnes, G. E. (2000). Soil Mechanics: Priciples and Practise (2nd Ed.), 91-93.

Bell, F. G. (1983). Engineering properties of soils and rocks. Oxford and ABH publishing, 22-40.

Blatt, H., \& Tracy, R. J. (1996). Petrology: Igneous, Sedimentary and Metamorphic (2nd Ed.), 359-365, Freeman.

Bolarinwa, A. T. (1992). Geological evolution of the residual clays in parts of Ekiti southwestern Nigeria. An unpublished M.Sc. Thesis. University of Ibadan.

Brooks, J. R. V., \& Whitten, D. G. A. (1972). The Penguin Dictionary of Geology.

Casangrande, A. (1948). Classification and Iidentification of soils. Transaction of the American Society of Civil Engineers, 113-901

Ekwueme, B. N. (2003). The Precambrian Geology and evolution of the Southeastern Nigeria basement complex, 6-13.

Elueze, A. A. (1993). Indications from Nigeria on the Industrialization and employment potentials of 
non-metallic mineral resources. AGID News, 74/75, 23-27.

Fabri, B., \& Fiori, C. (1985). Clays and complementary raw materials for stoneware title. Miner. Petrogr. Acta, 29-A, 535-545.

Fediro, O. O. (1998). An Introduction to the Technology of pottery (2nd Ed.), 6-21.

Feo-Codecido, G. (1956). Heavy minerals Technique and Application of Venezuela stratigraphy. AAPG Bulletin, 40(5), 984-1000.

McCarthy, D. F. (2001). Essentials of soil Mechanics and foundations: Basic geotechnics. $7^{\text {th }}$ ed., 28-37.

Meseguer, S. (2011). Geology and application of clays used in Castellon ceramic cluster (NE. Spain). Journal of Geography and Geology, 3(1).

Murray, H. H. (1960). Clay Industrial Minerals and Rocks (3rd ed). Publ. Am. Instit of Mining Metal and Pet Engineers, New York: Seeley. W. Mudd Series, p.284.

Oikonomopoulos, I., Perraki, Th., Kaouras, G., \& Antoniadis, P. (2007). Mineralogical study of inorganic intercalated seams Achlada lignite deposits (NW GREECE). Bulleting of the Geological Society of Greece, XXXVII, 906-917.

Oyawoye, A. O. (1964). The Geology of the Nigerian basement complex. Journal of Nigerian Min. Geol., l(1), 87-102.

Oyinloye, A. O. (1991). Application of kaolinitic clays in Industrial Clay technology TERRA. A Journal of Environmental Concern, 1(1), 68-72.

Parker, E. R. (1967). Materials Data Book for Engineers and Scientists. McGraw Hill Book Co., New York.

Paul, L. H., \& Brian, J. S. (Editors) (2000). The Oxford companion to the Earth. Oxford University press.

Pettijohn, F. J. (1941). Persistence of heavy minerals and geologic age. Journal of Geology, 49, 610-625.

Pettijohn, F. J. (1975). Sedimentary Rocks (3rd ed). New York: Harper and Row, 266-268.

Pettijohn, F. J., Potter, P. E., \& Silver, R. (1972). Sandstone and Sand. Springer verlag, New York, 303-306.

Selley, K. C., Cocks, L. R. M., \& Pliner, J. K. (2005). Encyclopedia of Geology Elsevier Acedemic Press.

Singer, F., \& Sonja, S. S (1971). Industrial Ceramics. London: Chapman and Hall, 18-56.

Velde, B. (1992). Introduction to clay minerals. Dumbleton M.J and West G. Journal: some factors affecting the relation between the clay minerals in soil and their plasticity.

\section{Copyrights}

Copyright for this article is retained by the author(s), with first publication rights granted to the journal.

This is an open-access article distributed under the terms and conditions of the Creative Commons Attribution license (http://creativecommons.org/licenses/by/4.0/). 